\title{
Dynamics of Dormancy-Status Subpopulations of Indian Ricegrass Seed Held in Dry Storage
}

\author{
T. A. Jones \\ Author is Research Geneticist, United States Department of Agriculture-Agricultural Research Service, Forage and Range Research Laboratory, \\ Departments of Wildland Resources and Plants, Soils, \& Climate, Utah State University, Logan, UT 84322-6300, USA.
}

\begin{abstract}
Germination of Indian ricegrass (Achnatherum hymenoides [Roem. \& Schult] Barkworth), a rangeland species native to western North America, is limited by persistent seed dormancy. We previously identified high-dormancy (HD) and low-dormancy (LD) genotypes from within the genetically heterogeneous cultivar Rimrock. Seed was produced in 2000 and 2001 in a common garden, stored in paper-can containers at room temperature, and tested every 3 mo with and without prechill through 2005 . In 2005 , tetrazolium viability of all four lots was $99 \%$, reflective of this species' extensive seed longevity. Over this time period, germination of nonprechilled seed increased from $1 \%$ to $53 \%$ for $\mathrm{HD}$ and from $15 \%$ to $79 \%$ for LD, whereas corresponding increases for prechilled seed were from $8 \%$ to $56 \%$ for HD and from $61 \%$ to $76 \%$ for LD. At first, the great majority of seeds of HD $(99 \%)$ and LD (86\%) were dormant, but this majority was overwhelmingly prechill nonresponsive for HD (92\%) compared to roughly equal portions of prechill-nonresponsive (39\%) and prechill-responsive (46\%) seed for LD. At the end of the trial, most seeds of both $\mathrm{HD}(53 \%)$ and LD $(79 \%)$ were nondormant, but more prechill-nonresponsive seeds were present in HD $(44 \%)$ than LD $(24 \%)$. Over the course of the study, the prechill-nonresponsive subpopulation declined more for HD (by $32 \%$ ), the prechill-responsive subpopulation declined more for LD (by 45\%), and overall dormancy (sum of the two subpopulations) declined more for HD (by 13\%). The prechill-responsive subpopulation was depleted more quickly than the prechill-nonresponsive subpopulation for both genotypes. Both HD and LD genotypes were responsive to room-temperature storage without loss of viability over a $4-5$-yr period. These data highlight the utility of long-term storage as a technique to improve germinability, and consequently establishment, success of Indian ricegrass.
\end{abstract}

\section{Resume}

La germinación de Indian ricegrass (Achnatherum hymenoides [Roem. \& Schult] Barkworth), una especie nativa de los pastizales del oeste de Norte América, es limitada por una persistente dormancia de la semilla. Inicialmente se identificaron genotipos con alta $(\mathrm{AD})$ y baja dormancia $(\mathrm{BD})$ dentro del cultivar Rimrock, un cultivar genéticamente heterogéneo. La semilla fue producida en 2000 y 2001 en un jardín común, almacenada en contenedores de papel a temperatura ambiente y evaluada cada tres meses con y sin frio previo a través de 2005. En 2005, la viabilidad en tetrazolio de los cuatro lotes fue de $99 \%$, un reflejo de la extensa longevidad de esta especie. Por encima de este periodo de tiempo, la germinación de semilla no almacenada en frio incrementó de $1 \%$ a $53 \%$ para $\mathrm{AD}$ y de $15 \%$ a $79 \%$ para $\mathrm{BD}$, mientras que la germinación observada en semilla almacenada en frio fue de $8 \%$ a $56 \%$ para $\mathrm{AD}$ y de $61 \%$ a $76 \%$ para $\mathrm{BD}$. Al principio, la gran mayoría de las semillas $\mathrm{AD}$ $(99 \%)$ y $\mathrm{BD}(86 \%)$ estuvieron latentes, pero la mayoría presentó una respuesta negativa a la exposición al frio para AD (92\%) comparada con porciones iguales de semilla $\mathrm{BD}$ que no presentó respuesta al frio $(39 \%)$ y otra que respondió positivamente al frio $(46 \%)$. Al final de la prueba, la mayoría de las semillas en $\mathrm{AD}(53 \%)$ y $\mathrm{BD}(79 \%)$ estuvieron no latentes, pero una mayor cantidad de semillas con respuesta negativa al frio fueron observadas en AD (44\%) comparadas con BD (24\%). Durante el resto del estudio, la sub-población de semilla que no respondió a la aplicación del frio declinó (32\%), para AD y (45\%) para BD y la latencia general (suma de las dos sub-poblaciones) declinó mas para $\mathrm{AD}$ (13\%). La sub-población que respondió al frio fue agotada más rápidamente que la sub-población que no respondió al frio en ambos genotipos. Los genotipos de AD y BD respondieron al almacenaje a temperatura ambiente sin perdidas en la viabilidad por encima de un período de cuatro a cinco años. Estos resultados resaltan la utilidad del almacenamiento a largo plazo para mejorar la germinación y consecuentemente el éxito en el establecimiento del Indian ricegrass.

Key Words: after-ripening, germination, seed dormancy

\section{INTRODUCTION}

Seed dormancy is a common feature of wildland species, such as Indian ricegrass (Achnatherum bymenoides [Roem. \& Schult] Barkworth), that functions to time germination so that environmental risks associated with seedling establishment are

Correspondence: T. A. Jones, 969 N 1100 E, Logan, UT 84322-6300, USA. Email: Thomas.Jones@ars.usda.gov

Manuscript received 1 November 2007; manuscript accepted 22 February 2009. minimized (Allen and Meyer 2002). In the process of domestication of crop species, such as rice (Veasey et al. 2004), selection has been applied for less recalcitrant germination in exchange for the provision of a relatively predictable seedbed environment. Likewise, a primary impetus for releasing Indian ricegrass plant materials for rangeland use has been enhanced germinability (Jones 1990).

Indian ricegrass is seeded primarily for rangeland restoration in western North America. Rapid germination is desirable for 
an initial seeding because weedy competitors are more likely to preempt resources for delayed germinants (Waldron et al. 2005). But this perennial must also be able to propagate itself indefinitely as a wild species. For this reason, the development of completely nondormant genotypes is probably undesirable. Nevertheless, commercial seed must be produced specifically for rangeland use, so a certain amount of domestication may be desirable to facilitate seed production. Currently, the most common practice is to sow in late fall to permit dormancy to break down over winter, thus facilitating spring germination (Jones and Nielson 1992; Jensen et al. 2001).

Stand establishment of Indian ricegrass is typically limited by low germination because of seed dormancy (Jones 1990). Huntamer (1934) described two dormancy mechanisms that she termed "physiological dormancy" and "mechanical dormancy," the latter being conferred by an indurate lemma and palea. Nikolaeva, as cited by Baskin and Baskin (2001), however, used the term "mechanical dormancy" to refer to the action of a hard, woody fruit wall. Indian ricegrass best fits in Baskin and Baskin's (2001) category of "nondeep physiological dormancy."

Toole (1940) attributed lemma/palea dormancy to these structures' exclusion of $\mathrm{O}_{2}$ from the seed, a mechanism recognized by Baskin and Baskin (2001) in their scheme. Lemma/palea dormancy is considered to be more difficult to break than the hormonal dormancy possessed by the seed itself (McDonald 1976). Mechanical scarification may break the lemma/palea barrier, which is believed to facilitate the further breakdown of dormancy by endogenous hormones (Griffith and Booth 1988; Jones and Nielson 1992).

Rogler (1960) reported that Indian ricegrass germination without prechill increased with age over 6 yr when stored in an unheated North Dakota attic, followed by a germination decrease as loss of viability exceeded loss of dormancy. Over several genotypes and production years, germination increased from $3 \%$ at 1 yr to $47 \%$ at 6 yr and then declined to $2 \%$ at 17 yr. These findings suggest that, after the lemma/palea barrier has been breached, Indian ricegrass seeds continue to possess hormonally mediated dormancy and become nondormant on loss of this dormancy.

In previous research (Jones and Nielson 1999), two genotypes, low-dormancy (LD) RR 6-6 and high-dormancy (HD) RR 3-15, were selected from cv. Rimrock (Jones et al. 1998). Averaged over 3 production years, germination with a 3 -wk prechill the spring following production was $57 \%$ for LD and $1 \%$ for HD (Jones and Nielson 1999). Averaged over 2 production years, lemma and palea thicknesses were $60.0 \mu \mathrm{m}$ and $49.9 \mu \mathrm{m}$ for LD and $65.2 \mu \mathrm{m}$ and $56.2 \mu \mathrm{m}$ for HD, suggesting the hypothesis that lemma/palea thickness and seed dormancy are positively correlated. Zemetra and Cuany (1984) had previously reported genetically controlled differences in lemma thickness and the absence of variation between two contrasting seed production environments, suggesting that this trait possesses high heritability.

My objective was to compare dormancy of 5-m-old LD and HD seed lots and to compare their loss of dormancy over 4-5 yr in dry storage. Every $3 \mathrm{mo}$, I compared germination of two contrasting genotypes (LD and HD) selected from the same genetic background, that is, Rimrock, with and without prechill. For each seed lot, I calculated the size of three viable seed subpopulations every 3 mo: 1) prechill-nonresponsive (PC-
NR), 2) prechill-responsive (PC-R), and 3) nondormant, that is, germinable without prechill. A fourth subpopulation is the nonviable fraction, as indicated by seeds testing negative with tetrazolium stain. I monitored changes in the sizes of the subpopulations over time in $\mathrm{HD}$ and $\mathrm{LD}$ seed lots stored at room temperature.

\section{MATERIALS AND METHODS}

Indian ricegrass is highly self-pollinated (Jones and Nielson 1989; Jones et al. 2007), and HD and LD are naturally occurring homogeneous inbreeding genotypes that represent the extremes for seed dormancy found in the genetically heterogeneous Rimrock (Jones and Nielson 1999), a wildland population originally collected at Billings, Montana, and since released as a cultivar (Jones et al. 1998). The two genotypes, HD and LD, each descend from individual Rimrock plants. Seed of the two genotypes was produced in adjacent plots at Cornish Farm (Cornish, Utah) in 2000 and 2001. Thus, the two seed lots were produced in the same seed production environment, which is critical because environment is known to have a large impact on Indian ricegrass seed dormancy (Jones and Nielson 1994). Because of the self-pollinated mating system of Indian ricegrass, genetic contamination between the two genotypes should be minimal.

Starting in December, about 5 mo following seed harvest, germination tests for the four seed lots were conducted at 3-mo intervals. Tests were conducted for $5 \mathrm{yr}$ for the 2000 seed lots and 4 yr for the 2001 seed lots. Seeds were stored at room temperature in paper-can containers for the duration of the study. On each test date, eight boxes (replications) of 100 seeds were tested for all combinations of genotype, production year, and prechill (with or without) treatment (including the initial date). However, because of a shortage of HD seed in the 2001 production year, each box had 100 seeds for the initial eight dates but only 50 for the latter eight dates.

Seeds were placed on $250 \mathrm{~g}(14 \mathrm{~mm})$ of sand (Owl Springs, Box Elder Co., Lucin, UT) in a $110 \times 110 \times 35 \mathrm{~mm}$ plastic germination box and buried with $180 \mathrm{~g}(10 \mathrm{~mm})$ of additional sand. Prior to use, sand was screened to remove any seeds of Owl Springs origin. A nontoxic steel blue germination blotter (Anchor Paper, St Paul, MN) was placed on top, $95 \mathrm{ml}$ of water were poured on the blotter, and the box was closed with a fitted lid. Soil matric potential at planting was approximately -0.17 $\mathrm{MPa}$ (R. W. Brown, personal communication, 1989), which is in the desirable range for germination in field-collected soil (Blank and Young 1992). Seedlings possessing both normal radicles and coleoptiles were counted following an 18-d (prechill) or 25 -d (nonprechill) germination period at $15^{\circ} \mathrm{C}$ in the dark (Association of Official Seed Analysts 2002). An extra week was allowed for nonprechill germination because germination rate is faster with prechill. In my experience, germination of Indian ricegrass seeds under these conditions is rapid and synchronous such that the time allotted is sufficient to measure germination percentage. Viability percentage based on 400 seeds was determined for all four seed lots by tetrazolium staining (Peters 2000) in September 2005 by the Utah State Seed Laboratory of the Utah Department of Agriculture and Food (Salt Lake City, Utah). 
Results were used to estimate the size of three viable seed subpopulations (the fourth subpopulation is nonviable) for each seed lot on each test date. Viable seeds that failed to germinate despite prechill were designated as PC-NR, calculated as viable seed percentage minus prechill germination percentage. Viable seeds that germinated with prechill but not without prechill were designated as PC-R, calculated as prechill germination percentage minus nonprechill germination percentage. Viable seeds that germinated without prechill were designated as nondormant. If the three viable seed subpopulations are added to the nonviable seed subpopulation, calculated as 100 minus the tetrazolium-stained percentage, the total is $100 \%$. It should be noted that when nonprechill and prechill germinations are similar, PC-R may be negative, as it is calculated by subtraction, that is, prechill germination minus nonprechill germination. In other words, although one would not expect the value of PC-R to be less than zero, its calculated value may be less than zero because of 1) subtraction of two similar values, both estimated with random error themselves, and/or 2) seed mortality occurring as a result of the prechill itself.

Data for the 2000 (first 16 of 20 test dates) and 2001 (all 16 test dates) seed production years were analyzed together using PROC GLM (Statistical Analysis System, Cary, NC). Each of the three viable seed subpopulations was analyzed as a dependent variable with genotype, test date, and year as independent fixed-effect variables in a complete factorial design. Eight boxes for each combination of genotype, year, and test date served as replications for PC-NR and nondormant subpopulation variables. For the nondormant subpopulation, the data set used to test significance of effects included nonprechill boxes only. For the PC-NR subpopulation, the data set used to test significance of effects included prechill boxes only. However, for the PC-R subpopulation, the data set used to test significance of effects included both nonprechill and prechill boxes. Because the presence of a real difference for $\mathrm{PC}-\mathrm{R}$ is synonymous with a real prechill/nonprechill effect, the genotype effect for PC-R was declared significant when the genotype $\times$ prechill/nonprechill effect was significant. Similarly, test date, year, and the three two-way and one three-way interaction effects were declared significant when the interaction of the corresponding effect with the prechill/nonprechill effect was significant. For presentation of the data, confidence intervals $(95 \%)$ were calculated for germination means with and without prechill for each seed lot on each date as well as for nondormant, PC-R, and PC-NR subpopulations.

\section{RESULTS}

As expected, the $2000 \mathrm{HD}$ seed displayed greater dormancy than 2000 LD seed with and without prechill at all test dates $(P$ $<0.05$; Fig. 1), reflecting the results of Jones and Nielson (1999). Differences were less dramatic for 2001 seed lots, but trends were similar. Analysis of variance showed that genotype $\times$ production year, test date $\times$ production year, and genotype $X$ test date $X$ production year interactions were significant (Table 1). Because the size of the genotype effect was large relative to the genotype $\times$ production year, the size of the test date effect was large relative to the test date $\times$ production year
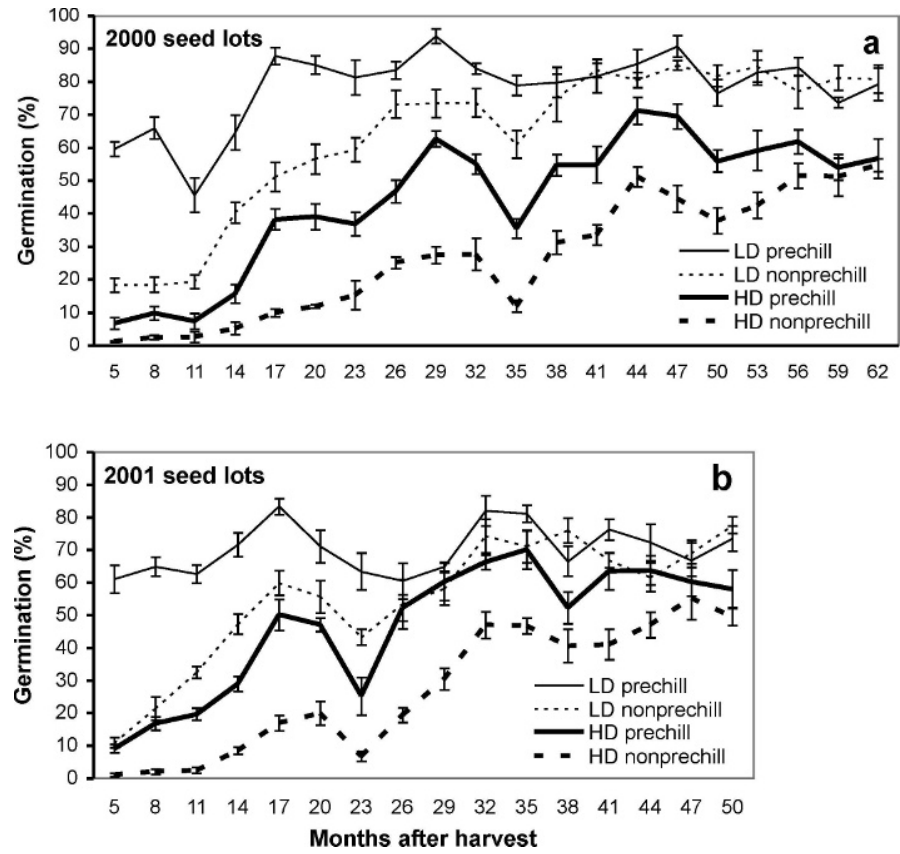

Figure 1. Prechilled and nonprechilled germination percentage means and $95 \%$ confidence intervals of low-dormancy (LD) and high-dormancy (HD) genotypes at 3-mo intervals in seed lots produced in 2000 (a) and 2001 (b).

effect, and the size of the genotype $\times$ test date effect was large relative to the genotype $\times$ test date $\times$ production year effect, I have chosen to emphasize genotype, test date, and genotype $\times$ test date effects. Therefore, I discuss the mean of the two seed lots (production years) unless otherwise indicated, but graphical presentation of the results of the two data sets are provided separately for inspection (Figs. 1 and 2).

At the beginning of the experiments, the majority of seeds of HD $(99 \%)$ and LD (86\%) were dormant. However, HD dormant seeds were overwhelmingly PC-NR (92\%), whereas for LD the two dormant subpopulations, PC-NR (39\%) and PC-R $(46 \%)$, were roughly equal in size. Eventually, nonprechilled germination equaled prechilled germination, but this occurred much more quickly for LD (41 mo after harvest for 2000 and 26 mo for 2001) than for HD (59 mo for 2000 and 47 mo for 2001). By the end of the experiments, the majority of seeds of both HD $(53 \%)$ and LD $(79 \%)$ were nondormant, but the PC-NR subpopulation was 20 percentage points greater for HD than for LD $(P<0.05$; Fig. 2$)$. Viability was $99 \%$ for all four seed lots at the end of the experiments despite roomtemperature storage for $4 \mathrm{yr}$ or $5 \mathrm{yr}$, meaning that the nonviable subpopulation was negligible.

The PC-NR subpopulation of HD was consistently greater than that of LD (Figs. 2a and 2b). However, because HD's PCNR subpopulation was depleted faster by emigration to the PC$\mathrm{R}$ subpopulation, the magnitude of this difference declined from 53 to 21 percentage points over the course of the experiments. Emigration from HD's PC-NR subpopulation increased the size of the HD PC-R subpopulation through the initial half of the experiments, a phenomenon not seen for LD.

Averaged over the course of the experiments, the size of the PC-R subpopulation showed much less difference between HD and LD genotypes than the PC-NR and nondormant subpop- 
Table 1. Analysis of variance for prechill-nonresponsive (PC-NR), prechill-responsive (PC-R), and nondormant subpopulations for high-dormancy and low-dormancy genotypes over 16 test dates and two seed production years.

\begin{tabular}{|c|c|c|c|c|c|c|c|c|c|}
\hline & \multicolumn{3}{|c|}{ PC-NR } & \multicolumn{3}{|c|}{ PC-R } & \multicolumn{3}{|c|}{ Nondormant } \\
\hline & df & $F$ & $P$ & df & $F$ & $P$ & df & $F$ & $P$ \\
\hline Genotype & 1,447 & 2840.4 & $<0.0001$ & 1,894 & 14.3 & 0.0002 & 1,447 & 4864.2 & $<0.0001$ \\
\hline Test date & 15,447 & 146.0 & $<0.0001$ & 15,894 & 24.4 & $<0.0001$ & 15,447 & 384.3 & $<0.0001$ \\
\hline Year & 1,447 & 3.1 & 0.0778 & 1,894 & 5.3 & 0.0214 & 1,447 & 3.0 & 0.0852 \\
\hline Genotype $\times$ test date & 15,447 & 38.3 & $<0.0001$ & 15,894 & 38.2 & $<0.0001$ & 15,447 & 23.2 & $<0.0001$ \\
\hline Genotype $\times$ year & 1,447 & 127.1 & $<0.0001$ & 1,894 & 2.2 & 0.1433 & 1,447 & 120.2 & $<0.0001$ \\
\hline Test date $\times$ year & 15,447 & 21.5 & $<0.0001$ & 15,894 & 5.1 & $<0.0001$ & 15,447 & 24.6 & $<0.0001$ \\
\hline Genotype $\times$ test date $\times$ year & 15,447 & 5.2 & $<0.0001$ & 15,894 & 2.8 & 0.0004 & 15,447 & 9.2 & $<0.0001$ \\
\hline
\end{tabular}

ulations (Table 1; Fig. 2). On the first test date, the PC-R subpopulation was 46 percentage points greater for LD than for HD (Figs. 2c and 2d), but as the experiment progressed, LD's PC-R subpopulation consistently declined (Figs. 2c and $2 \mathrm{~d})$ as seeds emigrated to the nondormant subpopulation (Figs. $2 \mathrm{e}$ and 2f). In contrast, the size of the HD PC-R subpopulation initially increased (Figs. $2 \mathrm{c}$ and $2 \mathrm{~d}$ ) because of immigration from the PC-NR subpopulation (Figs. 2a and 2b) but later declined as emigration to the nondormant subpopulation surpassed immigration from the PC-NR subpopulation (Figs. $2 \mathrm{a}$ and 2b). With the PC-R subpopulation of HD increasing and that of LD decreasing, the PC-R subpopulations of the two genotypes became not significantly different $(P>$ 0.05 ) in size at 20 mo for the 2000 seed lots (Fig. 2c) and 14 mo for the 2001 seed lots (Fig. 2d). Beyond this crossover point,
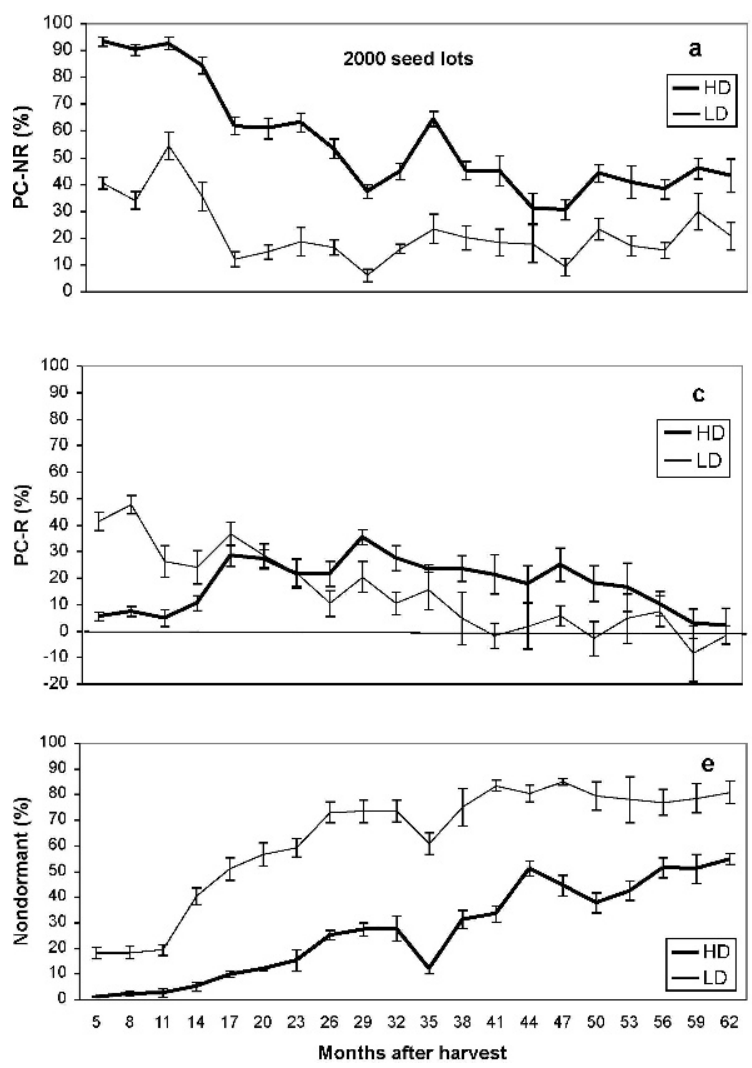

the size of the HD PC-R subpopulation usually exceeded that of LD. However, the size of both HD and LD PC-R subpopulations eventually approached zero (Figs. $2 \mathrm{c}$ and $2 \mathrm{~d}$ ).

The HD genotype's nondormant subpopulation was smaller than for LD at every test date $(P<0.05$; Figs. $2 \mathrm{e}$ and $2 \mathrm{f})$. The nondormant subpopulation size increased for both genotypes as the experiment progressed, but the two genotypes differed in the nature of this increase. Over the first half of the experiment, the increase in the nondormant subpopulation was much greater for LD, but the increase eventually slowed as LD's shrinking PC-R subpopulation was unable to provide additional emigrants to the nondormant subpopulation. In contrast, growth of HD's nondormant subpopulation was initially modest, but it showed faster growth in the middle of the experiment because of immigration from an increasing PC-R
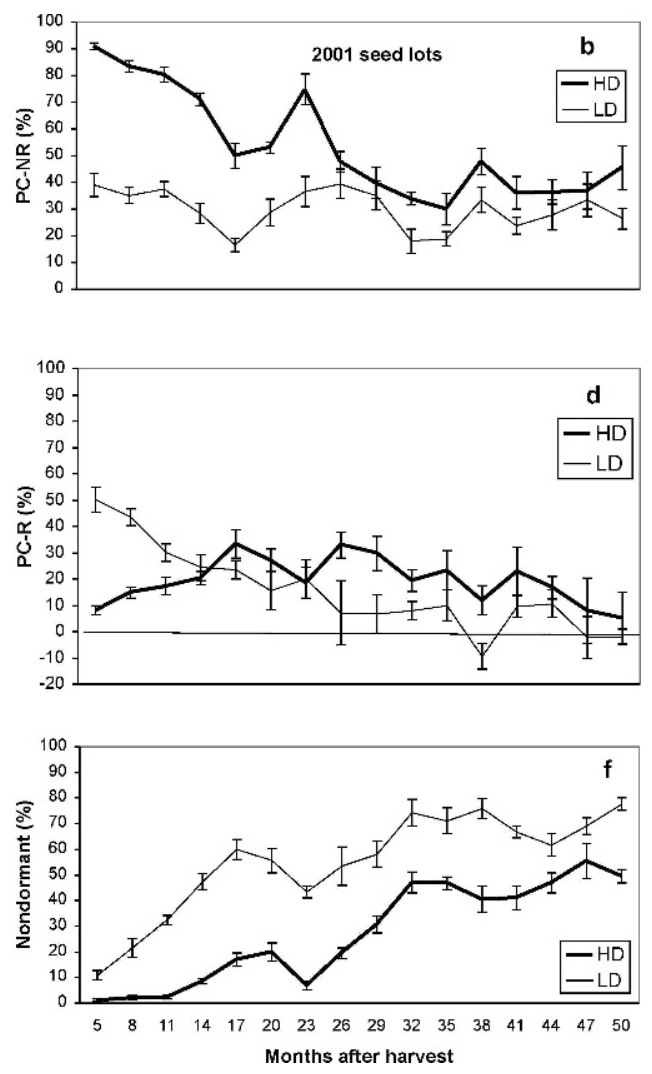

Figure 2. Prechill-nonresponsive (PC-NR), prechill-responsive (PC-R), and nondormant (ND) subpopulation means and $95 \%$ confidence intervals of high-dormancy (HD) and low-dormancy (LD) genotypes at 3-mo intervals in seed lots produced in 2000 (a, c, e) and 2001 (b, d, f). 
subpopulation. Toward the end of the experiment, the nondormant subpopulations of both LD and HD genotypes appeared to plateau but at a higher level for LD than for HD.

In summary, HD initially exhibited a larger PC-NR subpopulation (by 53 percentage points), but LD possessed a larger PC-R subpopulation (by 40 percentage points) and a larger nondormant subpopulation (by 14 percentage points; Fig. 2). At the final date, overall dormancy (PC-NR plus PC-R) of $\mathrm{HD}$, with a PC-NR subpopulation larger by 21 percentage points and a nondormant subpopulation smaller by 26 percentage points $(P<0.05)$, still exceeded that of LD. However, for the last four dates, sizes of the PC-R subpopulations of the two genotypes were similar $(P \geq 0.05)$ and approaching zero for both 2000 and 2001 seed lots despite emigration from their respective PC-NR subpopulations. The PC-R subpopulation was more quickly depleted than the PCNR subpopulation for both genotypes.

\section{DISCUSSION}

These data reaffirm that Indian ricegrass seed possesses considerable longevity (Rogler 1960). Indeed, to enhance germination, room-temperature storage of dormant seed lots is preferred over storage at $5^{\circ} \mathrm{C}$ because the former accelerated the loss of dormancy over an 11-12-mo period (Griffith and Booth 1988; Jones and Nielson 1992). Over our 4-5-yr study period, no evidence was found that HD and LD differed in longevity. However, differential viability may be greater in seed lots older than those evaluated here or in those that have been stored under more marginal conditions.

The two genotypes used here represent two extremes for seed dormancy within Rimrock, but certainly genotypes intermediate for seed dormancy are present in this cultivar as well. The presence of within-population genetic variation for seed dormancy has also been documented in downy brome (Bromus tectorum L.), an invasive, autogamous annual grass with an impressive ecological amplitude (Allen and Meyer 2002). Although this species has been present in North America for only about a century, these authors showed that genotypes evaluated from subalpine populations demonstrated little dormancy, whereas those from warm desert margins were consistently highly dormant. Furthermore, downy brome populations originating in extreme environments showed considerably less intrapopulation genetic variation for dormancy response than populations originating in intermediate environments. These results suggest that directional selection is operational for extreme environments, favoring a singledormancy genotype, whereas balancing selection is operational for intermediate environments, favoring multiple-dormancy genotypes.

Although here we report results for only a single Indian ricegrass population, previous work has shown differences in seed dormancy associated with sympatric seed morphs (Jones and Nielson 1999), where distinctive morphs are borne on plants of discrete genotypes (Jones et al. 2007). Many populations of Indian ricegrass are polymorphic, but the majority are not. Possibly nonpolymorphic populations from extreme environments possess little dormancy or extreme dormancy, as in downy brome.
Our data indicate that genotype impacts seed dormancy of Indian ricegrass by determining 1 ) initial sizes of PC-NR, PC-R, and nondormant subpopulations and 2) the dynamics of emigration from more dormant to less dormant subpopulations. Previous data showing that lemma and palea thickness are greater for HD than LD (Jones and Nielson 1999) suggest that thicker lemmas and paleas may inhibit germination, possibly by excluding $\mathrm{O}_{2}$ (Toole 1940). Similar results were reported for seeds of shadscale (Atriplex confertifolia [Torr. \& Frem.] Wats.), where lignified bracteole walls confer a mechanical barrier to germination (Garvin and Meyer 2003). This desert shrub requires chilling for a certain fraction of its seed, deemed to be cue responsive, but another fraction did not respond to the cue. Garvin and Meyer (2003) reported that proportions of cue-responsive seeds increased with dry afterripening over a period of $3 \mathrm{yr}$ of laboratory storage. The presence of both cue-responsive and cue-nonresponsive subpopulations permits 1) the germination of some seed in any year when conditions are favorable and 2) the generation of seed banks that persist across years. The cue-responsive fraction would correspond to the PC-R subpopulation discussed herein, and the cue-nonresponsive fraction would correspond to the PC-NR subpopulation.

\section{MANAGEMENT IMPLICATIONS}

Seed dormancy has always been the primary factor limiting stand establishment of Indian ricegrass. Because fall moisture is usually limited in the Intermountain Region, the standard practice is to establish dormant late-fall plantings that are intended to germinate the following spring when moisture conditions are more favorable. Plantings made too early in the fall, before temperatures have dropped significantly, are never recommended because germination may ensue and immature seedlings would be unlikely to survive the winter. This is a concern, not only for Indian ricegrass, but even more so for other species in the seeding mix that do not exhibit seed dormancy. This overwintering reduces dormancy and improves germination, but Indian ricegrass establishment could be further increased if the Bureau of Land Management paid a premium for older seed or was able to store the seed in a warehouse for a year or longer before being fall seeded. The extended longevity of Indian ricegrass seeds, as demonstrated here, means that storage for extended periods without danger of loss of viability is technically feasible. Resultant loss of dormancy would be expected regardless of the degree of dormancy, as was shown here with the HD and LD genotypes.

Furthermore, our results suggest that seeding a diversity of seed-dormancy genotypes has merit for accomplishing both seedling establishment and perpetuation of the seed bank. If desired, this is most easily accomplished by including both lowand high-dormancy genotypes in a seed mix. Such an approach may appeal to rangeland managers because this genetic diversity is a feature of naturally occurring Indian ricegrass populations (Jones and Nielson 1999; Jones et al. 2007). This approach also appeals to the ecological intuition that diversity contributes to the long-term survival of the seeded population. Released Indian ricegrass plant materials such as Rimrock represent the few exceptions to the generally recalcitrant 
germination of the germplasm of this species. Implementation of high-dormancy genotypes may be limited by their general unavailability in the seed trade.

\section{LITERATURE CITED}

Allen, P. S., and S. E. Meyer. 2002. Ecology and ecological genetics of seed dormancy in downy brome. Weed Science 50:241-247.

Association of Official Seed Analysts. 2002. Rules for testing seeds. Las Cruces, NM, USA: Association of Official Seed Analysts. 166 p.

BASKIN, C. C., AND J. M. BASKIN. 2001. Seeds-ecology, biogeography, and evolution of dormancy and germination. San Diego, CA, USA: Academic Press. $666 \mathrm{p}$.

Blank, R. R., AND J. A. Young. 1992. Influence of matric potential and substrate characteristics on germination of Nezpar Indian ricegrass. Journal of Range Management 45:205-209.

Garvin, S. G., and S. E. Meyer. 2003. Multiple mechanisms for seed dormancy regulation in shadscale (Atriplex confertifolia: Chenopodiaceae). Canadian Journal of Botany 81:601-610.

GrifFITH, L. W., AND D. T. Bоoth. 1988. Indian ricegrass seed damage and germination responses to mechanical treatments. Journal of Range Management 41:335-447.

HuntameR, M. Z. 1934. Dormancy and delayed germination of Oryzopsis hymenoides [dissertation]. Fargo, ND, USA: North Dakota State University. $83 \mathrm{p}$.

Jensen, K., H. Horton, R. Reed, and R. Whitesides. 2001. Intermountain planting guide. Logan, UT, USA: USDA-ARS and Utah State University Extension. AG 510. 104 p.

Jones, T. A. 1990. A viewpoint on Indian ricegrass research: its present value and future prospects. Journal of Range Management 43:416-420.

Jones, T. A., M. E. Majerus, J. G. Scheetz, L. K. Holzworth, and D. C. Nielson. 1998. Registration of "Rimrock" Indian ricegrass. Crop Science 38:539-540.
Jones, T. A., And D. C. Nielson. 1989. Self-compatibility in "Paloma" Indian ricegrass. Journal of Range Management 42:187-190.

Jones, T. A., AND D. C. Nielson. 1992. Germination of prechilled mechanically scarified and unscarified Indian ricegrass seed. Journal of Range Management 45:175-179.

Jones, T. A., AND D. C. Nielson. 1994. Indian ricegrass (Oryzopsis hymenoides) germination affected by irrigation and bagging during seed production. Arid Soil Research and Rehabilitation 8:305-311.

Jones, T. A., AND D. C. Nielson. 1999. Intrapopulation genetic variation for seed dormancy in Indian ricegrass. Journal of Range Management 52:646-650.

Jones, T. A., M. G. Redinbaugh, S. R. Larson, Y. Zhang, and B. D. Dow. 2007. Polymorphic Indian ricegrass populations result from overlapping waves of migration. Western North American Naturalist 67:338-346.

McDonald, M. B., JR. 1976. Improving the germination of Indian ricegrass seeds. Journal of Seed Technology 1:44-54.

Peters, J. 2000. Tetrazolium testing handbook-contribution no. 29 to the handbook on seed testing. Stillwater, OK, USA: Association of Seed Analysts. $23 \mathrm{p}$.

RogleR, G. A. 1960. Relation of seed dormancy of Indian ricegrass (Oryzopsis hymenoides [Roem. \& Schult.] Ricker.) to age and treatment. Agronomy Journal 52:470-473.

TOoLE, V. K. 1940. The germination of seed of Oryzopsis hymenoides. Journal of the American Society of Agronomy 32:33-41.

Veasey, E. A., M. G. Karasama, P. P. Santos, M. S. Rosa, E. Mamani, and G. C. X. OlivelRa. 2004. Variation in the loss of seed dormancy during afterripening of wild and cultivated rice species. Annals of Botany 94:875-882.

Waldron, B. L., T. A. Monaco, K. B. Jensen, R. D. Harrison, A. J. Palazzo, and J. D. KulBetr. 2005. Coexistence of native and introduced perennial grasses following simultaneous seeding. Agronomy Journal 97:990-996.

Zemetra, R. S., and R. L. Cuany. 1984. Variation in lemma thickness in Indian ricegrass: implications for dormancy, scarification, and breeding. Crop Science 24:1082-1084. 